\title{
Informasi dalam Perspektif Islam
}

\author{
Agus Sofyandi Kahfi \\ ABSTRACT \\ Today we faced an increasing number and forms of information delivered from media channels \\ throughout the world. The speed of change and the reach of (tele) communication technology \\ has shaped a new way of communication methods, new audience behavior, which in turn also \\ created a new cultural landscape. In Islamic perspective, information and communication \\ activities were perceived as a way to deliver thoughtful and moral messages to people. \\ The essence of communication lies in the process of expressing message effectively \\ by communications facilities. Communication must be done repeatedly in order to reach \\ intended effects. A communicator, therefore, has to acquire basics of communication method \\ to touch his/her audience. This article points out some basics of Islamic communication \\ which are no different with the principles of general communication.
}

Kata kunci: komunikasi Islami, informasi, prinsip-prinsip komunikasi

\section{Pengantar}

Di zaman pesatnya kemajuan teknologi seperti saat sekarang ini, sarana informasi sudah tersedia dalam segala bentuk dan variasinya. Informasi yang diterima masyarakat bisa melalui radio, media cetak, ataupun televisi. Oleh karena itu, informasi sekecil apa pun tidak bisa ditutu-tutupi; mulai dari berita kelaparan, musibah alam, isu korupsi dan suap, sampai dengan berita tentang perkawinan, perceraian, kehamilan, bahkan pencurian, perampokan dan pembunuhan, seluruh masyarakat bisa mengetahuinya melalui media yang tersedia. Kondisi ini, menunjukkan bahwa informasi sebagai kebutuhan dasar manusia untuk mengetahui segala hal yang terjadi di sekitar kehidupannya telah tersedia dengan lengkap.

Ketersediaan sarana informasi yang ada akan meningkatkan kemudahan manusia untuk mengirimkan, menerima, mengolah, dan menyimpan informasi secara lebih cepat dan tepat. Selanjutnya, dengan kemudahan-kemudahan yang ada, maka informasi dapat digunakan untuk memengaruhi sikap orang lain, memberikan dukungan psikologis kepada orang yang membutuhkan, bahkan dapat memengaruhi perubahan atau pembentukan tingkah laku dan kebiasaan orang lain.

Besarnya kekuatan informasi dalam memengaruhi penerimanya, menuntut adanya etika penyampaian informasi yang perlu diperhatikan oleh penyampai informasi. Bagaimana penyampai informasi mampu menunjukkan sikap profesional dan bertanggung jawab ketika mengajak orang lain untuk mau terbuka dan jujur dalam menyampaikan informasi, mau menunjukkan kesediaan untuk 
menunjukkan sikap menghargai posisi dan status subjek dan objek informasi serta menunjukkan kesediaan untuk memperlakukan subjek dan objek informasi secara horizontal dan demokratis, merupakan tuntutan yang memerlukan perhatian khusus dari setiap penyampai informasi.

Bagaimana Islam (dalam hal ini al Qur'an dan al Hadits) mengatur agar penyampaian informasi efektif dan tidak merugikan kedua belah pihak serta tidak keluar dari koridor penyampai informasi yang profesional dan bertanggung jawab, bisa kita telusuri beberapa keterangan yang ditukil Allah dalam al Qur'an dan hadits Nabi.

\section{Pengertian Komunikasi}

Pengertian komunikasi secara etimologis berasal dan perkataan Latin "Communicatio". Istilah ini bersumber dan perkataan "communis" yang berarti "sama". Sama di sini maksudnya sama makna atau sama arti. Jadi, komunikasi terjadi apabila terdapat kesamaan makna mengenai suatu pesan yang disampaikan oleh komunikator dan diterima oleh komunikan.

Beberapa pakar komunikasi memberikan definisi komunikasi yang di antaranya, dikutip Effendi. "Komunikasi adalah suatu proses di mana seseorang (komunikator) menyampaikan perangsang-perangsang, biasanya lambanglambang dalam bentuk kata-kata untuk mengubah tingkah laku orang lain (komunikan)" (Carl I. Hovland dalam Effendi, 1986:63)

Menurut Lewis Caroll, komunikasi merupakan "suatu proses memindahkan, mengoperkan, atau menyampaikan sesuatu secara teliti dari jiwa yang satu kepada jiwa yang lain. Hal itu adalah tepat seperti pekerjaan yang selalu harus kita ulangi dan ulangi lagi (Lewis Carol dalam Praktiko, 1982:10).

Tirman Sirait (1982:11) mengemukakan pendapatnya tentang pengertian komunikasi sebagai berikut: "Komunikasi adalah suatu tingkah laku, perbuatan, atau kegiatan penyampaian atau pengoperan lambang-lambang yang mengandung arti atau makna, atau informasi dari seseorang kepada orang lain, atau lebih. Jelasnya, suatu pemindahan atau penyampalan informasi mengenai pikiran dan perasaan-perasaan."
Dari beberapa definisi di atas, dapat diambil beberapa simpulan, yaitu:

(1) Komunikasi tidak berarti hanya menyampaikan sesuatu kepada orang lain, akan tetapi bagaimana caranya penyampaian sesuatu itu, agar yang penerima mudah mengerti dan memahami dengan perasaan yang ikhlas. Keberhasilan suatu komunikasi sangat dibutuhkan oleh faktor manusianya, karena manusia mempunyai akal dan pikiran serta perasaan untuk dapat menentukan sikap, dan manusia merupakan sarana untuk terjadinya suatu komunikasi.

(2) Hakikat komunikasi merupakan proses pernyataan antarmanusia yang berhubungan dengan pikiran atau perasaan seseorang kepada orang lain dengan menggunakan bahasa sebagai alat penyalurnya.

(3) Untuk mencapai komunikasi yang efektif dan efisien tidak semudah seperti yang dibayangkan. Banyak hal yang harus diperhatikan agar pesan atau pernyataan yang disampaikan kepada orang lain bisa dimengerti serta dipahami, seperti yang diharapkan oleh komunikator.

(4) Komunikasi tidak hanya dilakukan sekali saja, tetapi dilakukan secara berulang-ulang. Komunikasi akan berhasil dengan baik apabila timbul saling pengertian, yaitu jika kedua belah pihak si pengirim dan si penerima informasi dapat memahami pesan yang disampaikan.

Untuk mencapai keberhasilan suatu komunikasi, kita harus mengetahui lima unsur pokok yang terkandung dalam proses komunikasi. Kelima unsur komunikasi ini harus ada dalam suatu proses komunikasi, karena jika salah satu unsur tidak ada maka proses komunikasi tidak akan berlangsung dengan baik dan tidak akan mencapai hasil sesuai dengan yang diharapkan. Kelima unsur komunikasi tersebut meliputi:

(1) Komunikator, yaitu seseorang atau sékelompok orang yang menyampaikan pikirannya atau perasaannya kepada orang lain dalam bentuk pesan.

(2) Pesan/informasi, yaitu lambang bermakna yang membawa suatu pikiran dan komunikator. 
Komunikasi berlangsung pada umumnya menggunakan bahasa karena bahasa dianggap mampu untuk mengubah sikap seseorang.

(3) Komunikan, adalah seseorang atau sejumlah orang yang menjadi sasaran komunikator ketika ia menyampaikan pesan.

(4) Efek dan tanggapan, respon atau reaksi dan komunikan ketika ia atau mereka menerima pesan dan suatu kegiatan komunikasi.

(5) Media, yaitu sarana untuk menyalurkan pesan-pesan yang disampaikan oleh komunikator kepada komunikan.

\section{Persyaratan dari Pesan/Informasi}

Dalam upaya mencapai keberhasilan komunikasi, terdapat beberapa persyaratan yang perlu diperhatikan dalam kelima unsur komunikasi. Dalam unsur komunikan, misalnya, Efendi menyatakan bahwa seorang komunikan dapat dan akan menerima pesan hanya jika terdapat empat kondisi, yaitu: ia harus dapat dan benar-benar mengerti pesan dan penyampaian komunikator, pada saat mengambil keputusan, ia sadar bahwa keputusan itu sesuai dengan tujuan, pada saat ía mengambil keputusan, ía sadar bahwa itu bersangkutan dengan kepentingan pribadinya, ia mampu menempatkan keputusan, baik secara mental maupun fisik (Effendi, 1986:40, dalam Aramaniska W.F, 2006: 24).

Sedangkan dalam hal yang berkaitan dengan unsur pesan atau informasi, dikemukakan bahwa untuk menunjang lancarnya komunikasi yang efektif, seorang kumunikator harus mengetahui kondisi yang harus dipenuhi agar suatu pesan dapat membangkitkan tanggapan yang dikehendaki. Hal ini dikemukakan Wilbur Schramm yang di rumuskan di dalam bukunya yang berjudul The Condition of Success in Information dan dikutifoleh Effendi, 199:48 (dalam Armaniska, W.F, 2006 : 26-27) bahwa:

(1) Pesan harus dirancang dan disampaikan sedemikian rupa sehingga dapat menarik perhatian komunikan, pesan harus menggunakan lambang-lambang yang tertuju kepada pengalaman yang sama antara komunikator dan komunikan, sehingga samasama dimengerti.

(2) Pesan harus membangkitkan kebutuhan pribadi, komunikan dapat menyarankan beberapa cara untuk memeroleh kebutuhan tersebut.

(3) Pesan harus menyarankan suatu jalan untuk memeroleh kebutuhan yang layak bagi situasi kelompok di mana komunikan berada pada saat ía digerakkan untuk memberikan tanggapan yang dikehendaki."

Memperhatikan uraian di atas, dapat dinyatakan bahwa untuk mencapai atau untuk mengetahui suatu komunikasi yang efektif, hendaknya pesan disampaikan dalam bentuk yang jelas, menarik, dan dimengerti. Atau dengan kata lain, pesan yang disampaikan dirumuskan, dan direncanakan sehingga dapat mencapai satu kesamaan antara isi pesan dengan keinginan pribadi komunikator.

\section{Bentuk Informasi Islami}

Pesan/informasi yang disampaikan dan bertujuan untuk mencapai efektivitas pengaruh informasi yang tidak merugikan kedua belah pihak, al Qur'an dan al Hadits telah memberikan beberapa aturan yang perlu diperhatikan oleh setiap individu yang mengaku dirinya seorang Muslim, antara lain:

(1) Qashash/Naba al Haq, yaitu informasi yang disampaikan harus menggambarkan kisah, berita, dan informasi yang benar, terutama yang berhubungan dengan isi informasi yang disampaikan. Hal ini sejalan dengan pola al Qur'an dalam menceritrakan kisah yang terjadi pada para Rasul Allah dan berita tentang sekelompok atau individu manusia yang terjadi pada kehidupan masa lalu (lihat QS.11:120, 12:3 dan 18:13). Secara spesifik, al Qur'an menggambarkan bahwa informasi yang hak atau benar, memiliki karakteristik sebagai berikut:

(a) Informasi yang dapat meneguhkan hati penerima informasi, mengandung kebenaran, pengajaran, dan peringatan serta menyadarkan 
orang lain dari kelalaian ( lihat Q.S. 11:120).

(b) Informasi yang tidak menyembunyikan kebenaran yang perlu diketahui masyarakat dan mencampuradukkan berita benar dengan berita yang salah/batil (Lihat Q.S. 2:42 dan 146) atau yang mampu menyatakan bahwa suatu kebenaran itu adalah benar dan suatu kebatilan itu adalah memang batil (lihat Q.S.: 8:8) sekaligus informasi yang disampaikan tidak memihak salah ssatu pihak (adil) (lihat Q.S.: 49:9).

(c) Informasi yang dapat menyelesaikan perbedaan/pertentangan di antara penerima (lihat Q.S. 2:213) dan sekaligus dapat mendamaikan dari perselisihan meraka (lihat Q.S.49:9).

(d) Informasi yang dapat menghilangkan kemungkinan penerima informasi untuk mengemukakan praduga yang salah terhadap objek informasi (Allah dan orang lain) (lihat Q.S. 3:154).

(e) Informasi yang tidak hanya mengikuti kepuasan subjektif penyampai informasi yang cenderung tidak sesuai dengan kebenaran, tetapi informasi yang dapat mendorong munculnya semangat berkompetisi dalam berbuat kebaikan (sabiqun bil al kahiraat) serta dapat menyentuh rasa penerima informasi, sehingga mereka memiliki ketetapan hati tentang kebenaran yang diterimanya (lihat Q.S. 5:48 dan 83).

(2) A'mar ma'ruf nahyi munkar, yaitu informasi yang disampaikan diarahkan pada berkembangnya sarana saling mengingatkan untuk berbuat baik dan saling mencegah berbuat kemunkaran dan dosa. Dalam hal ini, informasi diarahkan pada berkembangnya nilai-nilai kebaikan dan berkurangnya nilai-nilai keburukan pada kehidupan si penerima informasi, baik dalam kehidupan dunia ataupun yang berkaitan dengan akhirat (lihat Q.S. 3:110).

(3) Hikmah, yaitu informasi yang disampaikan mengandung perkataan yang tegas dan benar yang dapat membedakan antara yang hak dengan yang batil. Tetapi, cara penyampaiannya mengandung nilai bijakasana, mengandung sentuhan kelembutan rasa dan menyentuh kesadaran kognitif yang tinggi, sehingga mampu membangkitkan motivasi penerima informasi untuk mempertahankan sikap dan tingkah laku yang baik dan mampu menumbuhkan kesadaran utuh untuk mengubah sikap dan perilaku yang buruk (lihat Q.S. 16:125).

(4) Tabayyun, yaitu informasi yang disampaikan telah melalui upaya klarifikasi. Artinya, menyampaikan informasi setelah dicari kejelasan dari sumber utama, bahkan beberapa sumber yang dianggap bisa memberikan kejelasan informasi (49:6), sehingga informasi yang disampaikan dapat bersifat adil (tidak berpihak). Begitu pula, penerima informasi bisa menentukan sikap yang adil (lihat Q.S. 49: 9).

(5) Mauizhah hasanah, yaitu informasi yang disampaikan mengandung contoh dan teladan yang baik untuk ditiru penerima informasi, baik melalui proses imitasi ataupun identifikasi (lihat Q.S. 16:125). Dalam hal ini, al Qur'an memberikan informasi yang mengandung contoh yang baik melalu gambaran tentang figur teladan bagi umat Islam. Antara lain, Luqman Al Hakim tatkala memberikan pengajaran terhadap anaknya. Atau, Ibrahim AS yang dinyatakan sebagai individu dengan $\mathrm{Al}$ Qalb Al Saliim (lihat Q.S. 31: 13-19 dan 26:78-89).

(6) Layyin, yaitu menyampaikan informasi dengan menggunakan tutur bahasa lemah lembut dan tidak keras serta kasar, sehingga si penerima informasi tidak tersinggung dan tidak berupaya untuk menutupi kekurangan dan kesalahan dirinya (lihat Q.S. 3:159).

Selain hal-hal di atas yang mengandung unsur anjuran atau perintah, maka dalam beberapa ayat bisa ditemukan beberapa keterangan yang mengandung unsur larangan atau pencegahan, di antaranya:

(1) Tidak skhariyyah dan talmizah. Artinya, informasi yang disampaikan tidak boleh mengandung unsur merendahkan harkat derajat orang lain dan tidak mengandung unsur mencela dan mencemarkan nama baik orang lain (lihat Q.S. 49:10 dan 104:1). 
(2) Tidak su'u al zhan. Artinya, informasi yang disampaikan tidak boleh mengandung kecurigaan dan buruk sangka serta berusaha mengikuti azas prduga tidak bersalah (husnu al zhan) (lihat Q.S. 49:11 dan 24:12 serta hadis Muslim dari Abu Hurairah dalam Sunan Al Baihaqi Juz 2, hal 238).

(3) Tidak tajaasas. Artinya, informasi yang disampaikan tidak boleh mengandung unsur mencari-cari kesalahan dan keburukan orang lain (lihat Q.S. 49:11dan Hadits Muslim dari Anas juga Abu Hurairah dan Shahih Muslim Juz 16, hal 405 dan 416).

(4) Tidak Ghibah. Artinya, menyampaikan informasi tidak boleh mengandung unsur menggunjingkan orang lain, yaitu menyampaikan suatu keburukan orang lain yang tidak diharapkan diketahui orang lainnya atau menyampaikan informasi tentang aib/cela seseorang kepada orang lain tanpa izin dan perkenan dari orang yang memiliki aib tersebut (lihat Q.S. 49:11 dan Hadits Muslim dari Abu Hurairah dalam Subul Al Salam, Juz :7, hal 167 serta Al Ashfahaani, Juz 1, hal 367).

(5) Tidak buhtan, yaitu menyampaikan informasi tidak boleh ditambah-tambah interpretasi subjektif dengan tujuan agar menjadi berita menarik dan menghebohkan (lihat Q.S. 16:62 dan 116)

(6) Tidak ifkun, yaitu tidak boleh menyampaikan berita yang sengaja dibalikkan dari fakta sebenarnya atau memutarbalikkan informasi yang benar menjadi bohong, dan perbuatan baik menjadi buruk dan tercela (lihat Q.S. 24:1218 dan Al Ashfahani, Juz 1 hal 19).

\section{Pembahasan}

Penyampaian dan penerimaan informasi merupakan salah satu tuntutan utama manusia dalam menjalani kehidupan dalam keluarga, bertetangga, di sekolah dan menjalani kehidupan bermasyarakat dan bernegara. Oleh karena itu, penyampaian dan penerimaan informasi, akan terjadi dalam proses komunikasi, baik yang terjadi dalam kehidupan sehari-hari ataupun dalam situasi dan kondisi yang sengaja disediakan untuk terjadinya komunikasi serta yang terjadi secara langsung atau tatap muka ataupun melalui media tertentu yang telah tersedia.

Komunikasi yang, di antaranya, diartikan Carl I. Hovland, sebagai suatu proses di mana seseorang (komunikator) menyampaikan perangsang-perangsang, biasanya lambanglambang dalam bentuk kata-kata untuk mengubah tingkah laku orang lain (komunikan), akan menuntut adanya penyampai informasi yang profesional dan bertanggung jawab, penerima infromasi yang selektif dan kritis, pesan/infromasi yang tepat dan akurat, media penyampaian informasi yang efektif dan adanya efek dari informasi yang telah disampaikan dan diterima.

Tuntutan-tuntutan yang ada dalam komunikasi, tidak terlepas dari adanya tujuan komunikasi, yaitu menyampaikan informasi dari satu pihak ke pihak lain, memeroleh informasi dari subjek atau objek informasi yang membutuhkan bantuan pemecahan dari masalah yang sedang dihadapi, serta memengaruhi terjadinya perubahan dan pembentukan sikap, tingkah laku, dan kebiasaan individu. Bagaimana penyampaian informasi agar bisa mencapai tujuan yang diharapkan, Islam melalui al Qur'an dan al Hadits telah mengajarkan agar informasi yang disampaikan merupakan informasi yang benar (bukan rumor) dan ada dalam koridor amar ma'ruf nahyi munkar serta telah dilakukan pengecekan (tabayyun) akan kebenaran dari informasi yang akan disampaikan. Selain itu, informasi yang disampaikan tidak mengandung unsur merendahkan, mencela, dan mencemarkan nama baik orang lain, tidak mengandung kecurigaan dan buruk sangka, tidak ada unsur mencari-cari kesalahan dan keburukan orang lain, tidak mengandung unsur menggunjingkan orang lain, tidak ditambahtambah interpretasi subjektif (buhtan) dan tidak memutarbalikkan fakta sebenarnya atau memutarbalikkan informasi yang benar menjadi bohong dengan tujuan menyebar fitnah (ifkun).

Mengenai kaharusan melakukan pengecekan (tabayyun) pesan/informasi yang akan disampaikan dan diterima, secara rinci diuraikan 
dalam al Qur'an Surat al Hujurat ayat 6, sebagai berikut: "Hai orang-orang yang beriman, jika datang kepadamu orang Fasik membawa suatu berita, Maka periksalah dengan teliti agar kamu tidak menimpakan suatu musibah kepada suatu kaum tanpa mengetahui keadaannya yang menyebabkan kamu menyesal atas perbuatanmu itu."

A. Mudjab Mahali dalam kitabnya, Asbabun Nuzul, menyatakan bahwa ayat ini berkaitan dengan kejadian yang terjadi pada seorang sahabat yang bernama Al Harits. Secara lengkap, kejadian ini diuraikan sebagai berikut: Al-Harits yang ikrar menyatakan dia masuk Islam. Rasulullah mengajaknya untuk mengeluarkan zakat, dan dia pun menyanggupi kewajiban itu seraya berkata, "Ya Rasulullah aku akan pulang ke kaumku untuk mengajak mereka masuk Islam dan menunaikan zakat. Barang siapa yang mengikuti ajakanku, aku akan kumpulkan zakatnya. Apabila telah sampai waktunya, kirimlah utusan untuk mengambil zakat yang telah aku kumpulkan itu".

Ketika AI-Harits telah banyak mengumpulkan zakat itu, dan waktu yang ditetapkan telah tiba, ternyata tak seorang pun utusan yang datang kepadanya. Al-Harits mengira telah terjadi sesuatu yang menyebabkan Rasulullah marah kepadanya. Dia memanggil para hartawan kaumnya dan berkata: 'Sesungguhnya Rasulullah telah menetapkan waktu untuk utus seseorang mengambil zakat yang telah ada padaku, dan beliau tidak pernah menyalahi janji. Akan tetapi, saya tidak tahu mengapa menangguhkan utusannya itu. Mungkinkah beliau marah? Mari berangkat menghadap Rasulullah saw.

Adapun Rasulullah saw. sesuai dengan waktu yang telah ditetapkannya mengutus Al-Walid bin Uqbah untuk mengambil dan menerima zakat yang ada pada Al-Harits. Ketika al-Walid berangkat, di perjalanan hatinya merasa gentar, sehingga dia pulang sampai di tempat yang dituju dan melapor kepada Rasulullah bahwa Al-Harits tidak mau menyerahkan zakatnya kepadanya, bahkan Al Harits akan membunuhnya".

Kemudian, Rasulullah mengirim utusan berikutnya kepada Al-Harits beserta sahabat- sahabatnya dan bertemu dengan utusan itu di perjalanan dan bertanya: "Kepada siapa engkau diutus?" Utusan itu menjawab: "Kami diutus kepadamu". Dia bertanya: "Mengapa?" Mereka menjawab: "Sesungguhnya Rasulullah saw. telah mengutus Al-Walid bin Uqbah. Dia mengatakan bahwa engkau tidak mau menyerahkan zakat, bahkan bermaksud membunuhnya". Al-Harits menjawab: "Demi Allah, yang telah mengutus Muhammad dengan sebenar-sebenarnya, aku tidak melihatnya, dan tidak ada yang datang kepadaku".

Sesampainya mereka di hadapan Rasulullah, maka bertanyalah, "Mengapa engkau menahan zakat serta hendak membunuh utusanku. Ia Menjawab: Demi Allah yang telah mengutusmu dengan sebenar-benarnya. Aku tidak berbuat yang demikian". Maka turunlah ayat 6 ini, yang merupakan peringatan buat kaum Mukminin untuk tidak menerima dengan begitu saja keterangan dan informasi dari sebelah pihak (A. Mudjab Mahali, 2002:765-766).

Adapun mengenai larangan tidak menambahnambah informasi dengan interpretasi subjektif (buhtan) dan tidak memutarbalikkan informasi yang benar menjadi bohong dengan tujuan menyebar fitnah (ifkun), berkaitan dengan berita bohong (buhtan dan ifkun) mengenai istri Rasulullah saw. 'Aisyah r.a. Ummul Mu'minin, sehabis perang dengan Bani Mushtaliq bulan Sya'ban 5 Hijriyyah. Perperangan ini diikuti oleh kaum munafik, dan turut pula 'Aisyah dengan Nabi berdasarkan undian yang diadakan antara istri-istri beliau.

Dalam perjalanan mereka kembali dari peperangan, mereka berhenti pada suatu tempat. 'Aisyah keluar dari sekedupnya untuk suatu keperluan, kemudian kembali. Tiba-tiba dia merasa kalungnya hilang, lalu dia pergi lagi mencarinya. Sementara itu, rombongan berangkat dengan persangkaan bahwa 'Aisyah masih ada dalam sekedup. setelah 'Aisyah mengetahui, sekedupnya sudah berangkat Dia duduk di tempatnya dan mengaharapkan sekedup itu akan kembali menjemputnya. Kebetulan, lewat ditempat itu seorang sahabat Nabi, Shafwan Ibnu Mu'aththal, diketemukannya seseorang sedang 
tidur sendirian dan Dia terkejut seraya mengucapkan: "Inna lillahi wa inna ilaihi raji'un, isteri Rasul!" 'Aisyah terbangun. lalu Dia dipersilahkan oleh Shafwan mengendarai untanya. Syafwan berjalan menuntun unta sampai mereka tiba di Madinah.

Orang-orang yang melihat mereka membicarakannya menurut pendapat masingmasing, mulailah timbul desas-desus tentang kedekatan Aisyah dengan Shafwan. Kondisi ini, kemudian dimanfaatkan kaum munafik, mereka membesar-besarkannya, sehingga fitnahan atas 'Aisyah r.a. itupun bertambah luas, sehingga menimbulkan kegoncangan di kalangan kaum muslimin.

Di sisi lain, cara menyampaikan informasi pun diajarkan Islam agar menggunakan cara yang halus, tidak keras dan kasar, mengandung contoh dan teladan yang baik untuk ditiru penerima informasi, serta mengandung nilai bijakasana yang sarat dengan sentuhan kelembutan rasa juga sentuhan kesadaran kognitif yang tinggi.

\section{Penutup}

Islam telah menentukan aturan-aturan yang perlu diperhatikan oleh seorang Muslim yang memiliki profesi sebagai pencari dan penyampai informasi. Aturan-aturan yang ditentukan Islam melalui al Qur'an dan al Hadits tentang etika yang perlu diperhatikan secara khusus oleh seorang pencari dan penyampai informasi adalah berhubungan dengan bentuk dan macam informasi yang akan disampaikan dan cara dan teknik penyampain informasi tersebut.

Semoga tulisan ini ada manfaat bagi para pembaca dan bisa memberikan kontribusi bagi pengembangan etika penyampaian informasi yang Islami.

\section{Daftar Pustaka}

Al A'liyy, “Al Qur'an Al Karim Dan Terjemahnya”, Bandung: CV. Dipenogoro.

Al Ashfahani, Al Raghib, “Al Mu'jam Mufradat al Fadz al Qur'an”, Beirut - Libanon: Dar al Fikr.

Al Shan'ani, Muhammad bin Ismail, "Subul al Salam”, Juz. 4, Bandung: Dahlan.

DeVito, Joseph A. 1989. "The Interpersonal Communication Book", Fifth Edition, New York: Harper And Row Publisher.

Fitriasih, W. Armaniska. 2006. "Hubungan antara persepsi terhadap efektivitas kumunikasi dengan penyesuaian sosial remaja di sekolah", (Skripsi, tidak dipublikasikan), Bandung: Fakultas Psikologi.

Ibnu Katsir, Ismail bin Umar. 1999. "Tafsir al Qur'an al A'zhim”, Dar Thayyibah li al Nasyar.

Mahali, A. Mudjab. 2002. “Asbabun Nuzul, Studi Pendalaman Al Qur'an”, Jakarta: PT. Raja Grafindo Persada.

Muslim, bin Al Hajaj, “Shahih Muslim”, BeirutLibanon: Dar al Fikr. 
